Pol. J. Food Nutr. Sci., 2019, Vol. 69, No. 1, pp. 83-99

DOI: $10.31883 /$ pjfns-2019-0008 http://journal.pan.olsztyn.pl

Review article

Section: Nutritional Research

\title{
Importance of Cheese Whey Processing: Supplements for Sports Activities - a Review
}

\author{
Patricia Fassina ${ }^{1,2}$, Gabriela Quadros Nunes ${ }^{1,2}$, Fernanda Scherer Adami ${ }^{2}$, \\ Márcia Inês Goettert ${ }^{3}$, Claucia Fernanda Volken de Souza ${ }^{1 *}$
}

\author{
${ }^{1}$ Laboratory of Food Biotechnology, Postgraduate Program in Biotechnology, \\ University of Vale do Taquari - Univates, Av. Avelino Tallini, 171, ZC 95914-014, Lajeado, RS, Brazil \\ ${ }^{2}$ Center of Biological and Health Sciences, Nutrition Course, University of Vale do Taquari - Univates, Lajeado, RS, Brazil \\ ${ }^{3}$ Cell Culture Laboratory, Postgraduate Program in Biotechnology, University of Vale do Taquari - Univates, Lajeado, RS, Brazil
}

Key words: dietary supplements, athletes, branched-chain amino acids, exercise

Whey protein (WP) is a highly nutritious, commercially available alternative food source that is used primarily as a food supplement by athletes and physically active individuals to provide them with essential amino acids and bioactive peptides, and additional benefits have been attributed to WP consumption. In this context, the objective of this review was to explore current evidence regarding the consumption of different WP supplements in sports nutrition to elucidate their efficiency in affecting muscle hypertrophy, physical performance, response to muscle injury, weight loss, and body composition changes. Furthermore, these effects were assessed by comparing whey protein hydrolysate (WPH), whey protein concentrate (WPC), and whey protein isolate (WPI) supplementation. Supplementation with WPI or WPC was related to increased muscle protein synthesis (MPS), and WPH caused muscle hypertrophy and improved physical performance. Compared to WPC and WPI, WPH improved peak torque associated with strength training without reducing the creatine kinase (CK) and tumor necrosis factor alpha (TNF- $\alpha$ ) levels in this type of physical activity, and the decreases in $\mathrm{CK}$ and lactate dehydrogenase (LDH) associated with aerobic exercise were significant. Supplementation with WPC resulted in weight loss, satiety, and improved body composition, without compromising whole-body lean mass loss. WPH was more effective than WPC and WPI regarding improved peak torque and muscle hypertrophy associated with strength training, and WPH reduced muscle damage associated with aerobic exercise via decreased CK levels.

\section{LIST OF ABBREVIATIONS}

ALA: $\alpha$-lactoalbumin; BCAAs: branched-chain amino acids; BF: body fat; BLG: $\beta$-lactoglobulin; BMI: body mass index; CBDdiet: carbohydrate breakfast diet; CHO: carbohydrates; CK: creatine kinase; CONC: concentric exercise; DRI: dietary references intakes; EAA: essential amino acids; ECC: eccentric exercise; EIMD: exercise-induced muscle damage; FAO: Food and Agriculture Organization; IOM: Institute of Medicine; IPT: isometric peak torque; LBM: lean body mass; LDH: lactate dehydrogenase; LIP: lipids; MP: milk protein; MPS: muscle protein synthesis; NWP: native whey protein; PBdiet: protein breakfast diet; PTN: proteins; RDA: recommended dietary allowance; REE: rest energy expenditure; RNS: reactive nitrogen species; ROS: reactive oxygen species; SPI: soy protein isolate; TNF- $\alpha$ : tumor necrosis factor alpha; WBdiet: whey protein breakfast diet; WC: waist circumference; WP: whey protein; WPC: whey protein concentrate; WPC-L: high-lactoferrin WPC; WPH: whey protein hydrolysate; WPI: whey protein isolate.

\footnotetext{
* Corresponding Author: Phone: +55 513714 7000; Fax: +55 513714 7001;

E-mail address: claucia@univates.br (C.F. Volken de Souza)
}

\section{INTRODUCTION}

The search for nutrients in alternative food sources has been widely explored [Oliveira et al., 2012]. Accordingly, whey, a product of cheese manufacture, has a significant commercial value due to its wide availability, low production cost, and a high nutritional value [Kankanamge et al., 2015]. Its use in the production of fruit-flavored dairy drinks, with fruit pulps such as acerola [Cappato et al., 2018] and chocolate [Monteiro et al., 2018] has increased, constituting an alternative to yogurt. It has also increased in the processing of dairy foods such as whey-grape juice [Amaral et al., 2018] and even in probiotic dairy drink formulations, added with inulin [Guimarães et al., 2018]. Whey accounts for approximately 20 to $30 \%$ of the total protein content of bovine milk [Devries \& Phillips, 2015]; $\beta$-lactoglobulin (BLG) $(45-57 \%)$ is the most abundant protein, followed by $\alpha$-lactoalbumin (ALA) (15-25\%), immunoglobulins (10-15\%), glycomacropeptide (10-15\%), bovine serum albumin $(10 \%)$, lactoferrin $(\sim 1 \%)$, and lactoperoxidase $(<1 \%)$ [Bendtsen et al., 2013].

BLG is composed of approximately $26 \%$ of branched-chain amino acids (BCAAs) (L-leucine, L-valine, and L-isoleucine) [Pal \& Radavelli-Bagatini, 2013], which are among 
the nine essential amino acids (isoleucine, leucine, lysine, methionine, phenylalanine, threonine, tryptophan, valine, and histidine) [Waitzberg \& Logullo, 2006], which are essential for muscle protein synthesis (MPS) [Burd et al., 2012] and, therefore, for muscle hypertrophy [Aoi et al., 2011]. Hypertrophy, increased lean body mass [Volek et al., 2013], and reduced muscle fatigue [Babault et al., 2014] are observed when strength training is followed by BCAA supplement ingestion because BCAAs minimize lean body mass loss and promote muscle regeneration [Aoi et al., 2011] after injuries caused by exhaustive exercise [Burd et al., 2012]. However, these processes occur as long as they are combined with a positive nitrogen balance [McArdle et al., 2014]; although all 20 different types of amino acids are essential to protein synthesis, the organism needs a dietary intake of the nine essential amino acids, including BCAAs. The absence or inadequate intake of any of these amino acids leads to a negative nitrogen balance, and might cause weight loss and hinder growth, which does not benefit the MPS process and muscle hypertrophy [Mahan \& Escott-Stump, 1998].

Using different technologies for production [Biocatalysts, 2014], whey proteins are sold as sports supplements termed whey protein (WP) [Haraguchi et al., 2006]. These products are available as whey protein concentrate (WPC), isolate (WPI), and hydrolysate (WPH) varieties [Pal \& Radavelli-Bagatini, 2013]. WPC contains approximately 25-89\% protein, with or without lactose; WPI has approximately 90-95\% protein, usually without carbohydrates; and WPH has higher peptide fractions [Marshall, 2004].

WP is a complete protein containing all the essential amino acids [Aoi et al., 2011] required for MPS [Stark et al., 2012], enabling muscle hypertrophy [Devries \& Phillips, 2015] and improved strength performance [Chen et al., 2014]. Furthermore, essential amino acids improve body composition [Devries \& Phillips, 2015], reduce immunosuppression and inflammation caused by muscle injury during physical training, and attenuate oxidative stress induced by exercise because they have antioxidant effects, and comprise a nutritional supplement also referred to as immune-nutrient [Cruzat et al., 2014]. In addition, other amino acids such as L-glutamine and L-arginine might also play these roles. Therefore, protein and amino acid supply is required for optimal synthesis and concentrations of immune-related proteins, including cytokines and antibodies. Amino acids will help regulate the main metabolic pathways of immune cells, from cell response to oxidative stress, and anti-inflammatory response, all of which are essential for an optimal immune function and for recovery from intense periods of physical training [Cruzat et al., 2014]. For athletes, WPH provides greater advantages over WPC and WPI [Biocatalysts, 2014] (Figure 1) because WP hydrolysis releases biologically active amino acids and peptides [Madureira et al., 2010].

However, for athletes and physically active people, the issue of whether to supplement remains controversial due to inconsistent data on WP varieties. Several factors, including dosage, mode of administration, intake time(s), duration of use, and integration into a specific physical training program, affect protein supplementation effects [Naclerio \& Larumbe-Zabala, 2016].

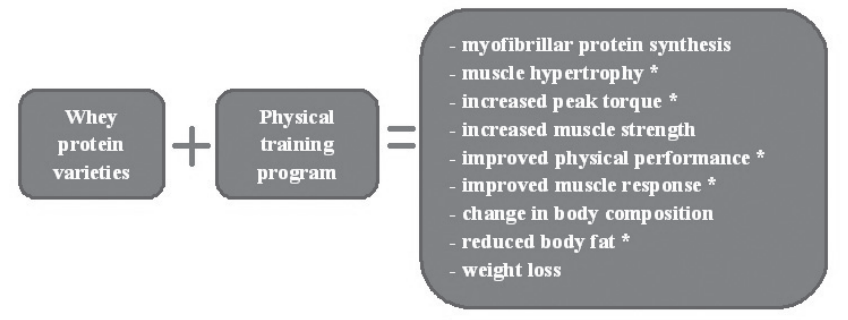

FIGURE 1. Effects of supplementation with WPC, WPI, and WPH combined with a physical activity program. *Greater advantage of WPH over WPC and WPI.

These factors highlight the need to review studies related to WP to elucidate its effects on hypertrophy, physical performance, response to muscle injury, weight loss, and change in body composition and to compare the effects of WPH, WPC, and WPI supplementation.

\section{EFFECTS OF WHEY PROTEIN CONCENTRATE, WHEY PROTEIN ISOLATE, AND WHEY PROTEIN HYDROLYSATE CONSUMPTION ON MUSCLE HYPERTROPHY AND PHYSICAL PERFORMANCE}

Muscle hypertrophy is the main objective of individuals seeking improved athletic performance. Muscle mass gain requires adequate nutrient intake and primarily requires protein [Rigon \& Rossi, 2012]. The recommended dietary allowance (RDA) of protein established by the Dietary References Intakes (DRI) of the Food and Nutrition Board of the Institute of Medicine (IOM) of the United States is $0.8 \mathrm{~g} / \mathrm{kg}$ weight/ day [IOM, 2002/2005]. However, protein intake greater than the RDA is required for individuals to optimize their adaptation to strength training [Chen et al., 2014]. These individuals should maintain moderate protein consumption ranging from 1.4 to $2.0 \mathrm{~g}$ protein/kg body weight/day [Jäger et al., 2017; Roberts et al., 2017].

Accordingly, the high-quality proteins and essential amino acids found in WP make this supplement one of the most widely used for MPS, ensuring good physical performance [Monteyne et al., 2018; Morton et al., 2018]. Table 1 outlines the results on muscle hypertrophy and physical performance from studies of supplementation with WPC, WPI, and WPH.

Muscle hypertrophy associated with WP supplementation can improve the performance of strength athletes and athletes who perform aerobic sports, such as marathons, cycling, and swimming [Chen et al., 2014]. Several studies on WPH supplementation before and immediately after each workout involving different physical exercises showed muscle hypertrophy [Farup et al., 2014b; Rahbek et al., 2014; Stefanetti et al., 2014].

Athletes who supplement with WPH before and after each running session in a combined daily intake of $1.8 \mathrm{~g}$ protein/kg weight per day showed improved functional strength and physical performance [Hansen et al., 2015]. Conversely, supplementation with WPH or WPC immediately before and after the daily workout in a combined daily intake of $1.3 \mathrm{~g}$ protein/kg weight per day failed to improve physical performance, and only WPC consumption increased muscle mass 


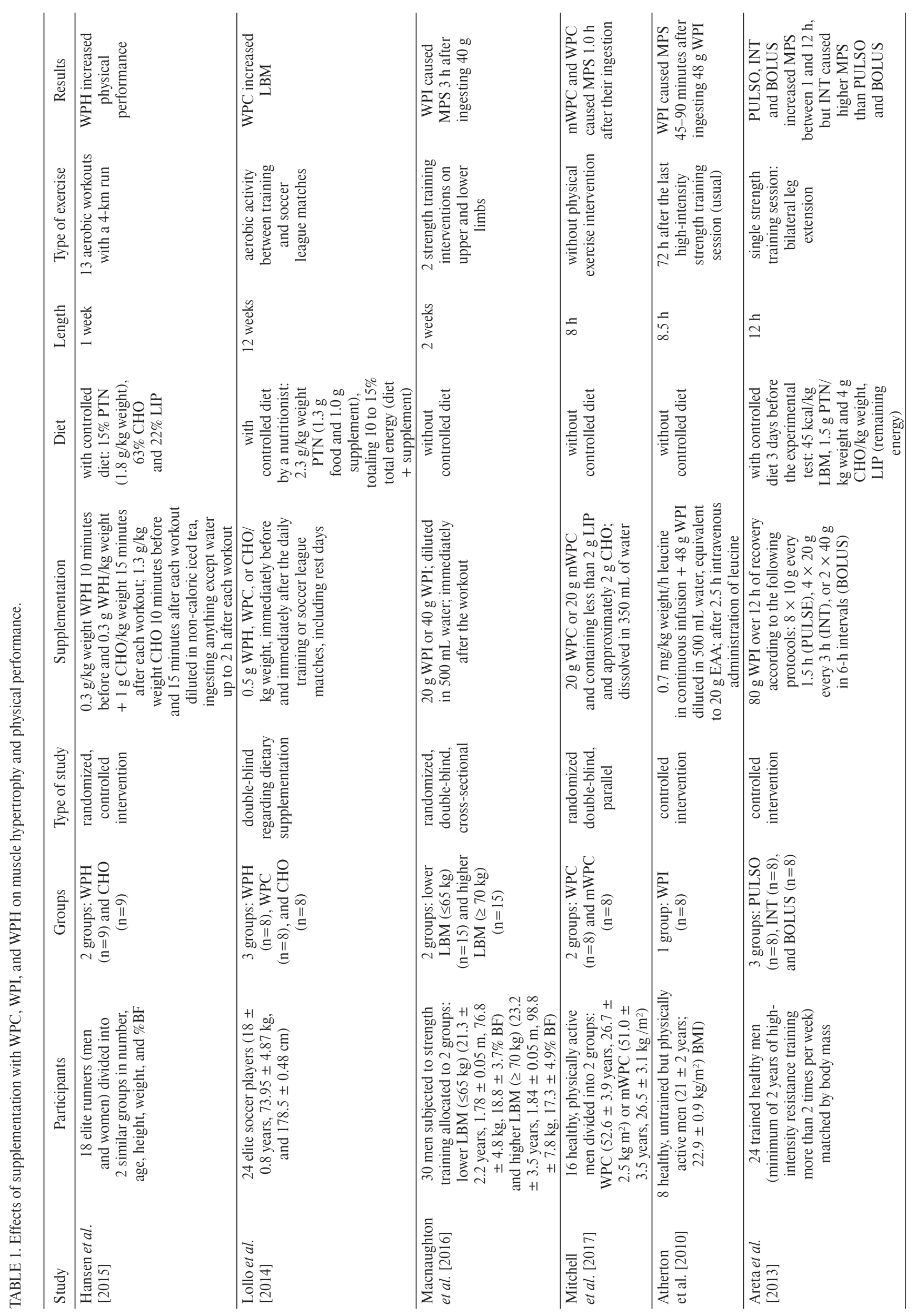




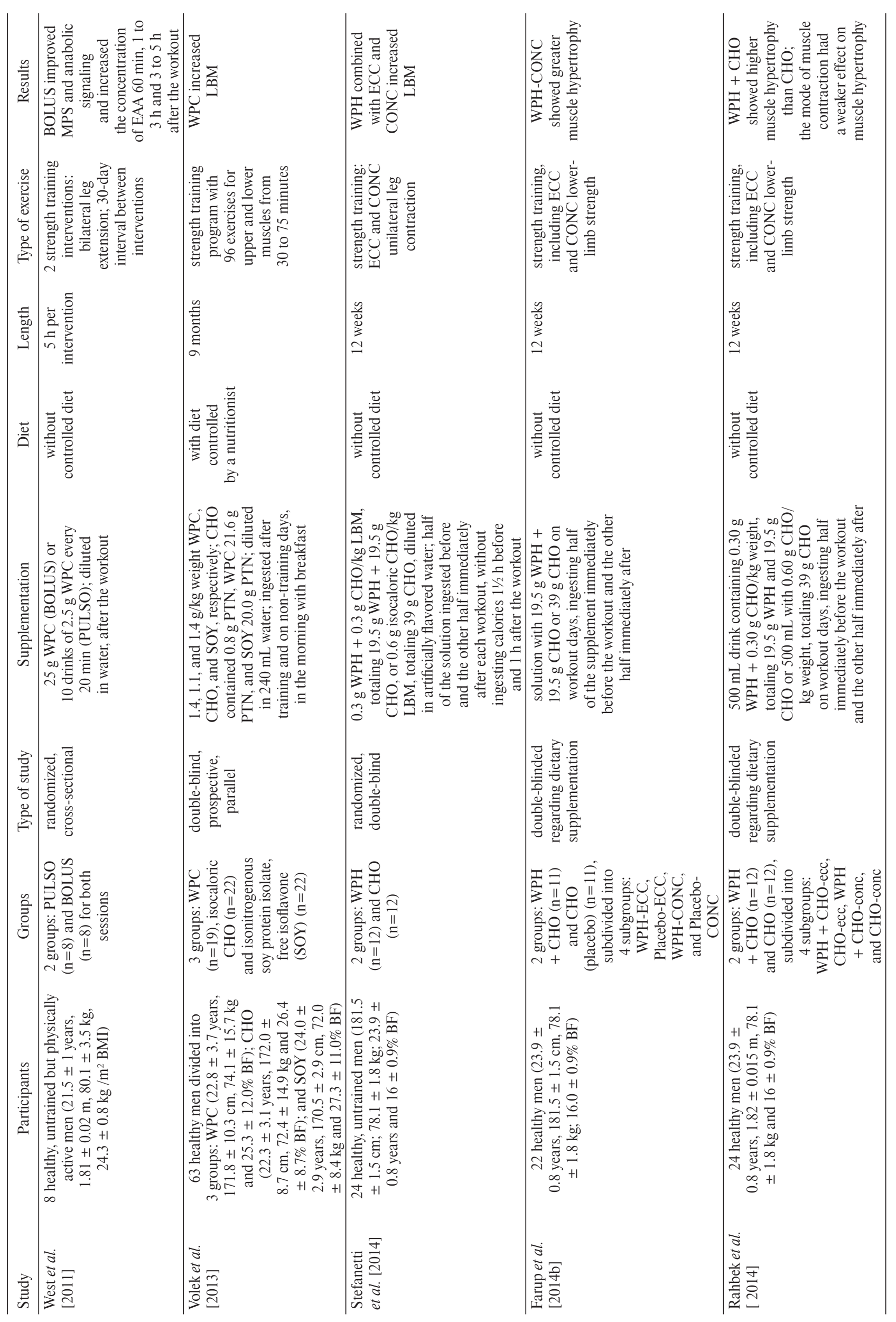




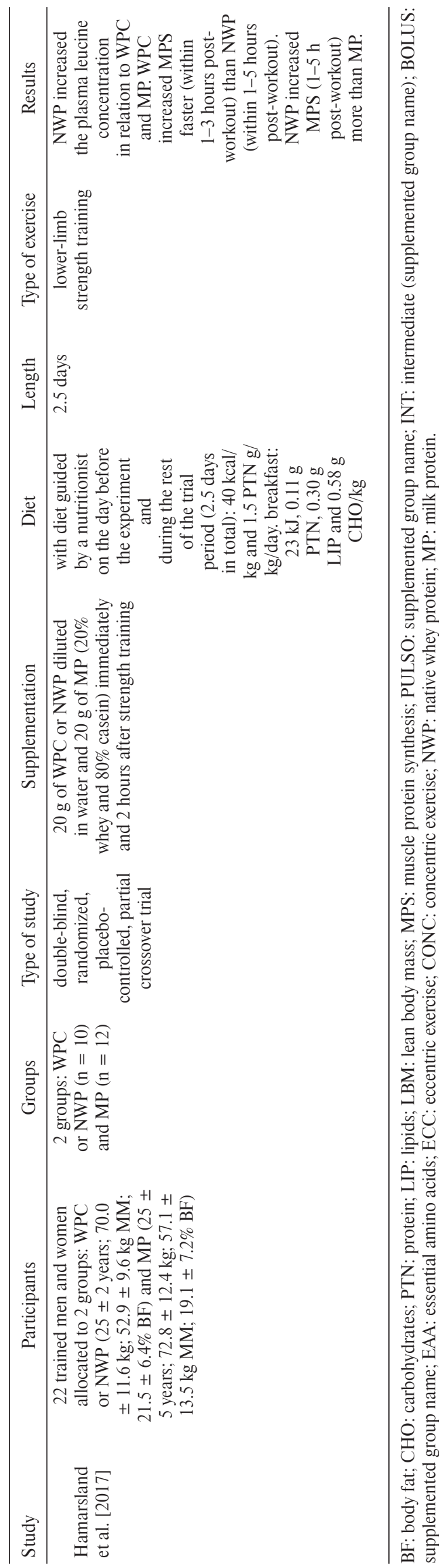

in soccer players [Lollo et al., 2014]. However, responses such as improved resistance and physical performance seem to indicate that a higher intake of proteins ( $1.8 v s \quad 1.3 \mathrm{~g}$ protein $/ \mathrm{kg}$ weight per day) from a diet that includes several types of protein sources maximizes the beneficial effects on the skeletal muscle when combined to WPH supplementation.

The combination of strength training and post-workout protein supplementation may enhance muscle protein synthesis, particularly in young people [Nogiec \& Kasif, 2013; Monteyne et al., 2018], as in these individuals protein supplementation after exercising might maximize MPS more easily than in older people, as the latter show more anabolic resistance of MPS to resistance exercise [Kumar et al., 2009]. However, a recent study by Jäger et al. [2017] concluded that protein intake before sleep increases overnight MPS and metabolism the next morning while improving muscle size and strength over 12 weeks of strength training, emphasizing that WP supplementation can also augment overnight MPS, during sleep, as well as after physical exercise, causing beneficial effects on the muscles of the organism [Jäger et al., 2017]. After ingestion, WP proteins are quickly digested and absorbed [West et al., 2011], thereby increasing the blood concentration of amino acids, especially leucine, resulting in rapid hyperaminoacidemia and particularly hyperleucinemia, which are crucial for the optimal stimulation of MPS, when it is not already initiating its maximal response [Devries \& Phillips, 2015]. Thus, protein supplements which are quickly ingested and that contain essential amino acids, mostly leucine, are more effective in stimulating MPS in active individuals, decreasing protein degradation, and possibly, helping in the recovery after exercising, provided they are combined with food with complete protein sources containing all essential amino acids [Jäger et al., 2017].

The RDA of leucine has not been established, and the optimal level varies with age and level of physical activity, as well as with energy consumption by the individual [Devries $\&$ Phillips, 2015]. The post-workout intake of up to $3 \mathrm{~g}$ leucine in young, trained individuals [Moore et al., 2009; Burke et al., 2012] or intake combined with strength training may maximize MPS [Farup et al., 2014a]. However, the need for higher intake was shown by Churchward-Venne et al. [2014], who found that adding $5 \mathrm{~g}$ leucine to $6.25 \mathrm{~g}$ WPI stimulates MPS. Despite these results, there are studies proving that leucine supplementation associated or not to WP supplement does not exert additional effects on MPS [Grala et al., 2017; Teixeira et al., 2018]. However, studies are still required to elucidate the influence of leucine on MPS as a potential nutritional ergogenic resource [Grala et al., 2017].

The rapid intake of WP, the hyperaminoacidemia caused by ingesting a large quantity of the same amino acid, the duration that the amino acids remain in the plasma, and the number of doses are some of the factors that enhance MPS [Cruzat et al., 2014] and generate different responses after WP consumption. West et al. [2011] noted that the MPS rates were highest $1-5 \mathrm{~h}$ after the strength training session. This time period is associated with peak aminoacidemia caused by the ingestion of $25 \mathrm{~g} \mathrm{WPC}$ in healthy men; the study compared this single ingestion with the intake of $2.5 \mathrm{~g}$ WPC every 20 min and concluded that the rapid aminoacidemia in the post- 
workout period improved MPS and anabolic signaling when the protein was administered more frequently and in smaller quantities. On the other hand, Areta et al. [2013], who administered WPI gradually, $20 \mathrm{~g}$ every $3 \mathrm{~h}$ after strength training for a 12-h period, suggest that more frequent and smaller quantity supplementation may be an optimal intervention. These results suggest that increased WP intake, e.g. 20 to $25 \mathrm{~g}$, in one single ingestion stimulates MPS more than repeated protein supplementation in small portions [West et al., 2011] and that the effect of modulating the distribution of protein intake on anabolic responses in the skeletal muscle has the potential to maximize training results, reaching the peak of muscle mass [Areta et al., 2013].

Furthermore, leucine consumption through WP varieties helps MPS. In a recent study by Mitchell et al. [2017], improved muscle synthesis was observed $1 \mathrm{~h}$ after consuming WPC microparticles (mWPC) or WPC, both with similar leucine concentrations, in physically active, healthy young men. Similarly, supplementation with WPI and leucine shortens MPS compared with supplementation exclusively with WPI [Macnaughton et al., 2016]. Atherton et al. [2010] observed increased MPS after 45-90 min when WPI intake was combined with the intravenous injection of $0.7 \mathrm{mg}$ leucine $/ \mathrm{kg}$ weight/h for $8.5 \mathrm{~h}$.

Furthermore, native WP, produced by raw, unprocessed milk filtration, which is a production method that maintains milk proteins intact, has a higher leucine content than WPC, which is derived from whey [Hamarsland et al., 2017]. These authors also compared MPS in response to two 20-g doses of WPC or native WP ingested immediately and two hours after strength training and observed that native WP increased blood leucine concentrations more than WPC, although the MPS rates increased faster with WPC (within 1-3 hours post-workout), whereas native WP increased MPS rates within 1-5 hours post-workout. These results suggest that WP supplementation with leucine maximizes its effect on MPS and that leucine in connection with exercise plays a unique role in the regulation of MPS [Moberg et al., 2014]. Previous studies also suggest that leucine, composition of the protein, and rapidly ingested amino acids in the bloodstream are the major factors that determine MPS response [West et al., 2011].

According to the Food and Agriculture Organization [FAO, 2013], protein quality varies according to its amino acid content, digestibility, and bioavailability. Plant protein sources are frequently inferior in one or more essential amino acids and thus fail to meet the requirements of complete proteins, such as those contained in whey [Joy et al., 2013]. Therefore, WP quality is related to its high biological value and the content of essential amino acids [Aoi et al., 2011; Atherton et al., 2017]. Increased gains in lean body mass were observed in individuals who consumed daily isocaloric WPC supplements compared with those who consumed soy protein isolate and carbohydrates, thus highlighting the importance of protein quality in strength training [Volek et al., 2013]. This discrepancy occurs because strength training combined with WP supplementation is associated with increased lean body mass compared with other isoenergetic supplements containing carbohydrates or other sources of protein [Naclerio \& Larumbe-Zabala, 2016].
However, in addition to type, the effects of protein supplementation on the concentration of blood amino acids will depend on quantity [Mitchell et al., 2015] and state (whether solid or liquid) required to increase the concentration of blood amino acids, i.e., cause aminoacidemia [Baer et al., 2011], as well as absorption time and kinetics of plasma amino acids [Burd et al., 2012]. That is why consuming protein supplementation within $1 \mathrm{~h}$ after strength training is ideal for promoting hypertrophy and gains in muscle strength [Stark et al., 2012].

As mentioned above, protein intake regulates muscle protein synthesis in response to repeated anabolic stimuli to maintain and promote MPS, which should be considered in the development of nutritional strategies [Areta et al., 2013]. According to Devries \& Phillips [2015], although protein intake is the strongest predictor of muscle hypertrophy after strength training, diets with a 20 to $35 \%$ higher protein content of total daily energy consumption maximize muscle hypertrophy compared with protein intake only a few hours before and/or after strength training. Furthermore, the quantity of muscle mass may also affect MPS, given the increased demand for amino acids, which may be met by exogenous sources [Macnaughton et al., 2016]. However, a protein intake higher than $2.0 \mathrm{~g} / \mathrm{kg}$ weight/day is unlikely to provide additional gains in lean body mass [Pasiakos et al., 2013].

Protein supplements, essential amino acids, and leucine increase MPS rates while decreasing muscle protein degradation and possibly enhancing recovery after exercise [Jäger et al., 2017], although whether protein supplementation promotes hypertrophy and increases muscle strength gain remains unclear [Erskine et al., 2012] because studies have limitations, including small sample size, inaccurate measures of muscle size and strength, lack of control over previous training programs or regular protein intake, and issues with the study period or number of study variables [Nogiec \& Kasif, 2013]. Furthermore, the individual response to strength training may vary between subjects [Erskine et al., 2010], and this effect may be reduced by the increased experimental control of physical activity and protein intake [Erskine et al., 2012]. The lack of studies measuring MPS also prevents the establishment of an RDA of protein during the muscle recovery period [Areta et al., 2013].

EFFECT OF SUPPLEMENTATION WITH WHEY
PROTEIN CONCENTRATE, WHEY PROTEIN
ISOLATE, OR WHEY PROTEIN HYDROLYSATE ON
MUSCLE INJURY

The inflammation that occurs in response to muscle damage is induced and aggravated by the increased production of reactive oxygen species (ROS) and reactive nitrogen species (RNS) [Cruzat \& Tirapegui, 2009]. Although physical training stimulates ROS production, the intracellular ROS concentration may not reach harmful levels due to the increase in and adaptations of antioxidant system responses [Cruzat et al., 2014]. However, inadequate physical training and a single, high-intensity training session or excessive physical training may cause changes in the redox states, oxidative stress [Petry et al., 2014], muscle fatigue, and muscle injury [Cruzat et al., 2010]. 
A significant release of hemoglobin-derived $\mathrm{Fe}^{2+}$ ions occurs during specific types of exercise, particularly those involving eccentric contractions [Welch et al., 2002]. Therefore, damage to erythrocyte membranes [Koury \& Donangelo, 2003] may enhance oxidative stress, leading to fatigue and muscle damage [Niess \& Simon, 2007] and thereby impairing athletic performance [Koury \& Donangelo, 2003]. Moreover, ROS and RNS production may induce an increase in intracellular $\mathrm{Ca}^{2+}$ concentrations and inactivate several enzymes involved in anaerobic and aerobic metabolism, leading to muscle fatigue [Duhamel et al., 2005].

Muscle injury, neutrophil infiltration, and ROS generation are directly related to the initiation of the inflammatory response and depend on the intensity, type, and duration of physical exercise [Niess \& Simon, 2007; Petry et al., 2014]. Furthermore, during the recovery period, immunity may become compromised, thereby contributing to chronic inflammation [Cruzat et al., 2014] through considerable changes in the immune function.

The effects of exercise on the immune system are mediated by changes in the production of hormones, such as adrenaline, cortisol, and growth hormone, and pro- and antiinflammatory cytokines [Cannon, 2000]. The increase in circulating proinflammatory cytokines induces edema and pain and worsens inflammation until this increase is reversed and recovery from muscle injury is established [Cruzat \& Tirapegui, 2009].

Among the pro-inflammatory cytokines, tumor necrosis factor alpha (TNF- $\alpha)$ stands out [Rohde et al., 1997]. TNF- $\alpha$ induces inflammatory responses involving the release of cytokines that persist for up to 5 days, resulting in the pronounced accumulation of neutrophils and macrophages in the damaged tissue, where these cytokines perform key functions for damaged tissue repair [Tsivitse et al., 2003]. Circulating TNF- $\alpha$ levels increase one- to two-fold after strenuous and prolonged training [Ostrowski et al., 1999], and their pro-inflammatory effect decreases during moderate exercise due to the increase in anti-inflammatory cytokines [Cruzat et al., 2014], as the effects of exercise-induced cytokines depend on the type of mediator involved and on the balance between pro-inflammatory cytokines (IL-1, TNF- $\alpha$, IFN $\alpha$, IFN $\gamma$, TNF- $\beta$, IL-2, IL-12 e MCP-1) and anti-inflammatory cytokines (IL-4, IL-10, IL13, IL-12p40, IL-1ra). While performing moderate exercises, the production of pro-inflammatory cytokines is negatively regulated and that of anti-inflammatory cytokines is positively regulated [Rohde et al., 1997]. During strenuous and prolonged exercises, there is an increase in the levels of circulating pro-inflammatory cytokines, such as TNF- $\alpha$, counterbalanced by the production of the anti-inflammatory cytokine IL-10 [Ostrowski et al., 1999]. Therefore, plasma IL-1 and TNF- $\alpha$ concentrations increase one- to two-fold, while IL-6 might increase over 100 times in the skeletal muscle after the practice of prolonged physical exercises, causing IL-6 to stimulate the circulation of anti-inflammatory cytokines IL-1ra and IL-10, thus inhibiting the production of the pro-inflammatory cytokine TNF- $\alpha$ [Ostrowski et al., 1999].

Intense and prolonged physical training [Brancaccio et al., 2008] also increases the serum levels of creatine kinase (CK) [Brancaccio et al., 2007] due to cell membrane rupture [Wal- lace, 2011], which damages the sarcomere of skeletal muscle cells [Brancaccio et al., 2007]. The CK levels tend to peak 16-24 $\mathrm{h}$ after the workout and remain high for approximately $72 \mathrm{~h}$ [Uchida et al., 2009]. Increased lactate dehydrogenase (LDH) activity, indicative of muscle cell injury, is also seen when mechanical tension is applied to muscle fibers during exercises due to the increased sarcolemma permeability, which releases $\mathrm{LDH}$ into the bloodstream and increases its concentration [Van De Vyver \& Myburgh, 2012].

Nutritional supplements that contain proteins and amino acids, such as WP, may contribute to reduced immunosuppression and excessive inflammation [Cruzat et al., 2014], accelerating muscle function recovery after strength training, although the evidence for this assumption remains unclear [Kim et al., 2017]. A systematic review made by Davies et al. [2018] demonstrated a mild-to-moderate ergogenic effect of WP use on the acceleration of muscle function recovery after strength training. Table 2 outlines the effects of supplementation with WPC, WPI, or WPH on the response to muscle injury induced by strenuous physical training.

The repair of damaged muscle tissue can be shown by assessing the activity levels of LDH [Brancaccio et al., 2008] and $\mathrm{CK}$ because they are indicators of muscle injury [Soares et al., 2012]. Significant decreases in CK and LDH were observed by Lollo et al. [2014] when WPH was provided to soccer players before and after aerobic training. The study by Brown et al. [2018] found that in physically active women, WPH supplementation immediately and $2 \mathrm{~h}$ after muscle damage induced by repeated sprint exercises also promoted greater reductions in CK. Similarly, WPH intake before and after each aerobic workout, as proposed by Hansen et al. [2015], attenuated the increase in CK, thus indicating that protein supplementation facilitated recovery from strenuous training among elite runners, despite the increase in $\mathrm{LDH}$ and the failure to alter TNF- $\alpha$ levels.

The reductions in muscle damage and acceleration of recovery from muscle injury caused by strenuous physical exercise may be related to the use of WPH supplementation [Brown et al., 2018]. These findings are in line with the study by Lollo et al. [2014], in which supplementation with WPC immediately before and after daily training sessions or soccer league matches showed a trend toward increased $\mathrm{CK}$ and LDH levels, and with the study by Hamarsland et al. [2017], in which CK levels increased upon intake of two 20 -g doses of WPC-80, native WP or milk protein $(20 \%$ whey and $80 \%$ casein), both immediately and two hours after strength training. Furthermore, other authors found no improvement in muscle damage markers (CK and TNF- $\alpha$ ) or muscle pain in individuals supplemented with a $0.4 \mathrm{~g} / \mathrm{kg}$ mixture of WPC with WPI 30 min before and after exercise, both with the short-term diet with high protein content $(2.9 \mathrm{~g}$ protein $/ \mathrm{kg} /$ day) and with diet with moderate protein content (1.8 g protein $/ \mathrm{kg} /$ day), after repeated days of intensive training [Roberts et al., 2017].

Supplementation with WPH decreased the muscle damage indicators $\mathrm{CK}$ and $\mathrm{LDH}$ but failed to improve physical performance, increase muscle mass, or decrease body fat compared with supplementation with WPC among soccer players undergoing aerobic training [Lollo et al., 2014]. 


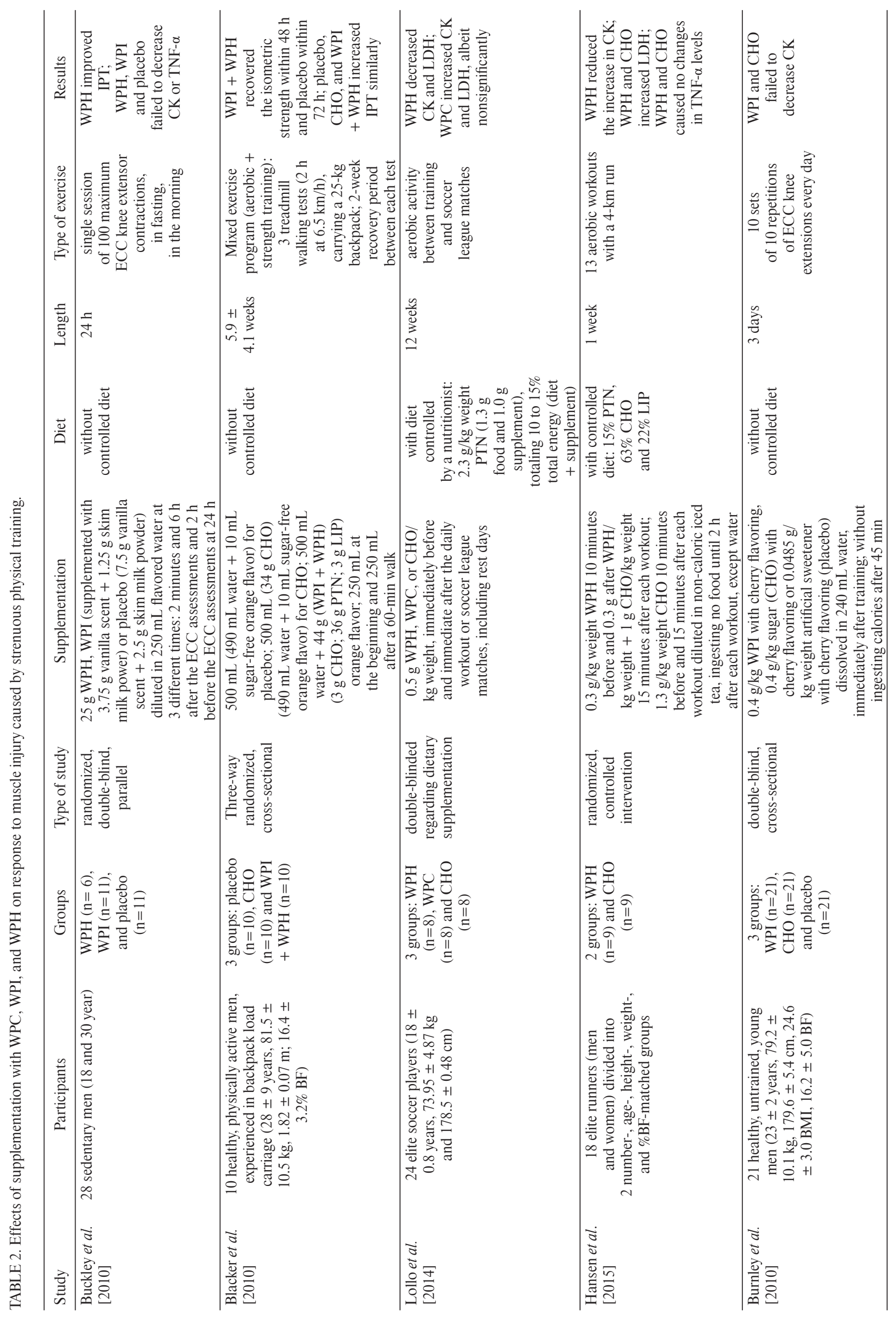




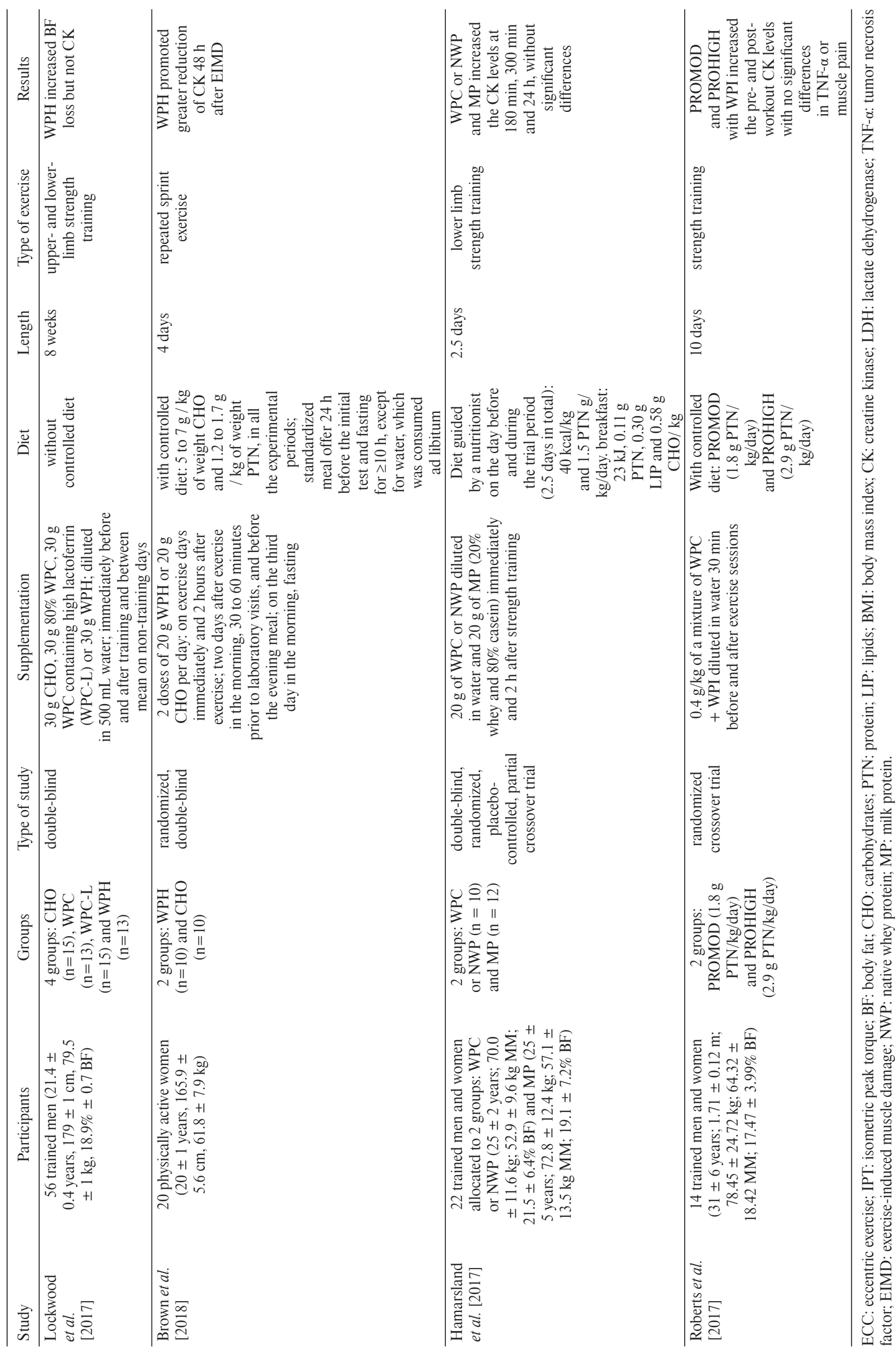


When comparing WPH and WPI intake, Buckley et al. [2010] noted that WPH intake accelerated the recovery of strength capacity and muscle regeneration after a single session of eccentric exercise, although no significant differences in the serum activity of CK or in the plasma levels of TNF- $\alpha$ were found. This rapid recovery of strength capacity and muscle regeneration during bodybuilding exercises results from the increased rate of MPS and increased strength gains induced by WP compared with other dietary proteins because WP proteins in WPH are rapidly digested and absorbed due to the hydrolysis process [Burd et al., 2012].

In contrast, Burnley et al. [2010] determined that WPI supplementation immediately after moderate eccentric exercise had no significant effect on muscle recovery in young men, most likely because the muscle injury was light and the supplement dose was low. The authors concluded that a small quantity of protein supplementation might be insufficient to affect muscle injury recovery. The TNF- $\alpha$ and CK levels also remained unchanged in the study by Buckley et al. [2010], which may be explained by the short study period because serum CK activity can take up to $48 \mathrm{~h}$ to increase. Additionally, the absence of any effect on the plasma levels of TNF- $\alpha$ after maximal eccentric contractions may have resulted from the short duration of the exercise protocol used.

Strength generation capacity and accelerated recovery from muscle injury were observed $6 \mathrm{~h}$ after exercise when supplementation with WPH was performed 2 min after exercise, and the same improvements were also observed at $24 \mathrm{~h}$ after 2 additional administrations at $6 \mathrm{~h}$ and $22 \mathrm{~h}$ in experiments involving the induction of fatigue and injury in sedentary men [Buckley et al., 2010]. Isometric strength, as assessed by treadmill walking with a $25-\mathrm{kg}$ load on the back, was recovered within $48 \mathrm{~h}$ when a WPI + WPH combination was administered. Protein supplementation favored the maintenance of an anabolic environment, which may have improved the repair of structural muscle proteins damaged during prolonged exercise with load, leading to the recovery of isometric muscle function [Blacker et al., 2010].

Therefore, for athletes, WPH has greater advantages than WPC or WPI [Biocatalysts, 2014] because WPH is digested and absorbed more rapidly [Burd et al., 2012] and shortens the recovery from muscle injury caused by strenuous physical exercise from days to hours [Biocatalysts, 2014]. It is likely that an increase in the supply of amino acids through WPH supplementation is responsible for accelerating repair of damaged skeletal muscle and its capacity to generate force [Brown et al., 2018].

EFFECT OF SUPPLEMENTATION WITH WHEY
PROTEIN CONCENTRATE, WHEY PROTEIN
ISOLATE, OR WHEY PROTEIN HYDROLYSATE
ON WEIGHT LOSS AND CHANGE IN BODY
COMPOSITION

Protein intake has been related to satiety and reduced energy intake compared with other macronutrients [Monteyne et al., 2018]. However, this satiety effect is dependent on the protein source [Chungchunlam et al., 2017]. WP supplements may be a good choice for a weight loss diet due to the presence of proteins BLG and ALA [Bendtsen et al., 2013]. ALA is considered to be easily and quickly ingested, having the highest content of tryptophan $(6 \%)$ among all sources of food proteins [Markus et al., 2002], thus being considered a source of tryptophan, a precursor of serotonin, which is known to suppress food intake and satiety [Halford et al., 2011]. This makes the intake of ALA-enriched proteins, such as WP, a precursor of increased levels of tryptophan and serotonin in the brain [Markus et al., 2002].

Weight loss and increased satiety were observed upon consumption of an energetic breakfast with a high-protein content from WPC relative to other sources of protein (eggs, tuna and soy) [Jakubowicz et al., 2017]. The results also showed that the satiating effect of WPI was similar to that of BLG or ALA due to rapid protein digestion and absorption, high concentrations of amino acids in the bloodstream [Bendtsen et al., 2013] and the release of gastrointestinal hormones related to satiety, including cholecystokinin, glucagon-like peptide-1, and peptide tyrosine [Jakubowicz \& Froy, 2013]. A rapid whey protein intake is more satiating than that of intact proteins, such as casein, slowly digested in the short term and quickly digested in the long term, which might be partially explained by the difference in blood amino acid rates and postprandial secretion of gastrointestinal hormones [Bendtsen et al., 2013].

In addition to the satiating effect and weight loss, WPH may help modulate weight and reduce body fat [Bendtsen et al., 2013]. Supplementation with WPH immediately before and after strength training and between meals on non-training days reduced body fat to a greater extent than supplementation with WPC (80\%) or high-lactoferrin WPC (WPC-L) [Lockwood et al., 2017]. However, according to the authors, further research is required to elucidate in which form WPH affects adipose tissue physiology.

In addition to regular physical training, high-protein diets (Table 3) may have beneficial effects on anthropometry and body composition. Supplementation with WPC 30 minutes before lunch has beneficial effects on the appetite, caloric intake, anthropometry, and body composition of overweight and obese male workers [Tahavorgar et al., 2014]. Conversely, Chungchunlam et al. [2017] found no significant decrease in hunger, satiation, or energy intake in "ad libitum" meals.

The decrease in body fat mass is related to the intake of different protein varieties. For example, a study assessing the intake of a commercial WPI + WPC + WPH supplement 20 minutes before a high-intensity strength training session in trained men and women showed an increase in resting energy expenditure, which is an effective strategy to reduce body fat mass without decreasing muscle mass [Hackney et al., 2010]. Weight loss without affecting muscle mass occurred in young men with WPI intake 5 minutes after the strength training session when followed by a full meal 60 minutes after supplementation [Monteyne et al., 2018]. According to Devries \& Phillips [2015], the increase in protein intake increases the gains in lean body mass during strength training and enhances high-quality weight loss.

Supplementation with WPC decreased total body and abdominal fat and increased muscle mass when administered to untrained men after strength training [Hulmi et al., 2015] 


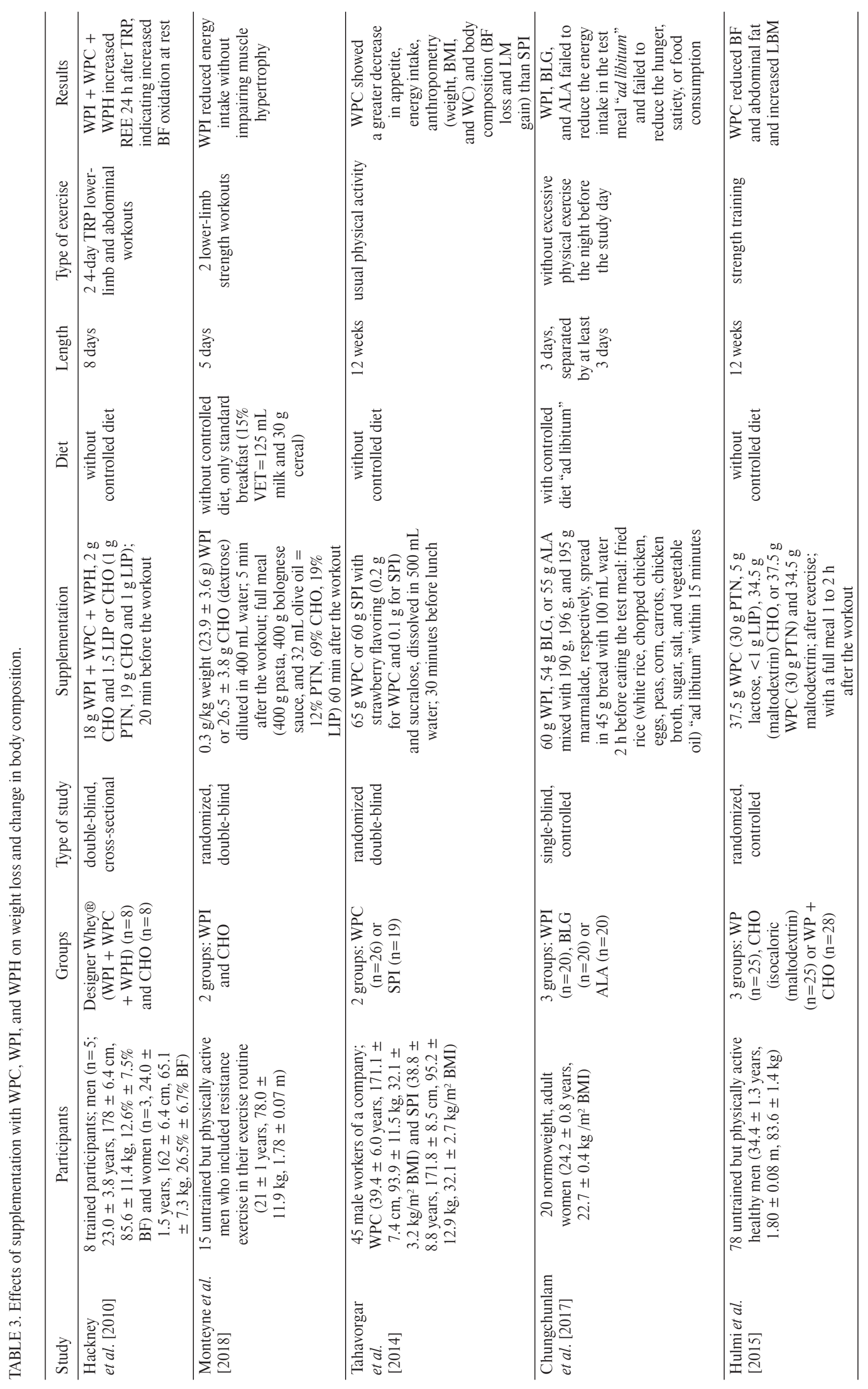




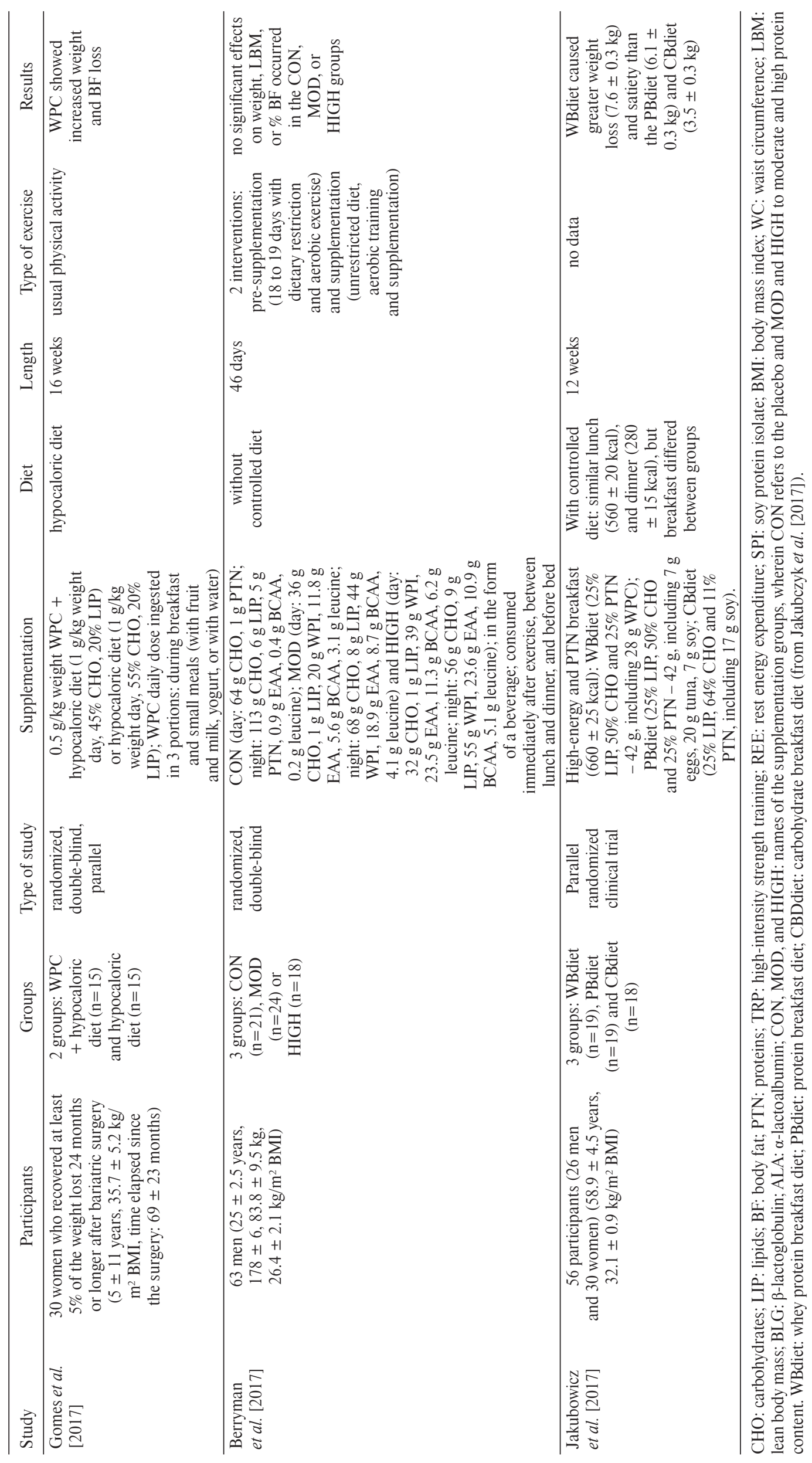


and promoted weight and body fat loss among women [Gomes et al., 2017]. These results can be attributed to the WP content, which correlates with decreased energy consumption because it increases satiety, thereby decreasing energy consumption [Bendtsen et al., 2013] and/or increasing resting energy expenditure [Hackney et al., 2010]. Furthermore, these proteins participate in beta-oxidation processes [Acheson et al., 2011] and lipolysis [Hector et al., 2015] and can be recommended for body fat loss after strength training [Hulmi et al., 2015]. Conversely, Berryman et al. [2017] found no changes in weight, lean body mass, or body fat measurements in young men supplemented with WPI 3 times per day immediately after aerobic physical exercise in the morning, between lunch and dinner, and before bed.

Nutritional monitoring and a training program in line with an individual's goals are important for realizing beneficial effects from the consumption of different WP formulations because protein supplementation alone will most likely fail to cause the expected effects. As shown above, the RDA established by the DRI for the population is a key tool for nutritionists. Accordingly, the quantity of daily protein that should be ingested by a sedentary adult is $0.8 \mathrm{~g} / \mathrm{kg}$ weight/ day [IOM 2002/2005], whereas this need will vary with the individual's physical training intensity and objectives. According to the Brazilian Society of Exercise and Sports Medicine [Sociedade Brasileira de Medicina do Exercício e do Esporte, 2009], an intake of 1.2 to $1.6 \mathrm{~g} / \mathrm{kg}$ protein/day is recommended for endurance athletes, whereas strength athletes may benefit from an intake of 1.6 to $1.7 \mathrm{~g} / \mathrm{kg}$ protein/day, although an intake higher than $3.0 \mathrm{~g} / \mathrm{kg}$ protein/day may benefit body composition [Jäger et al., 2017]. To optimize protein supplementation, nutritionists must evaluate the individual's diet, lifestyle, sports modality, goals, and training phase before choosing the supplement.

This study examined available evidence regarding the effects of consuming different varieties of WP on muscle hypertrophy, physical performance, response to muscle injury, weight loss, and body composition changes. However, this review had limitations due to difficulties in comparing studies that involve various methods and include small groups, heterogeneous samples, and differences in age, trained or untrained individuals, dosage, administration routes, supplement varieties, the degree of diet control, the study period length (ranging from hours to months), and the physical training modalities. These difficulties stress the need for further studies on WP supplementation with larger and more homogeneous samples and study periods longer than 12 weeks. Furthermore, more specific training protocols, which should focus on hypertrophy, physical performance, response to muscle injury, weight loss, and changes in body composition, are needed and should be adequately integrated with the supplementation protocol to consider dosage, administration route, and food intake to obtain more consistent results.

\section{CONCLUSION}

The papers analyzed in the present study showed that supplementation with either WPI or WPC was related to increased MPS and that WPH caused muscle hypertrophy and improved physical performance. Few studies showed results concerning muscle damage regarding the efficacy of WP varieties in reducing cell damage markers monitored by $\mathrm{CK}$, $\mathrm{LDH}$, and TNF- $\alpha$. A higher reduction in weight, satiety, and improved body composition occurred with WPC supplementation, without compromising bodily lean mass loss.

WPH intake provided more advantages compared to WPC and WPI, and improved muscle torque and hypertrophy peak associated to strength exercise and reduced muscle damage, caused by reduced $\mathrm{CK}$ levels associated to aerobic exercises. With these findings, the present study contributes to assign the WP variety according to its use by athletes, sportspeople, and general population.

\section{RESEARCH FUNDING}

We would like to thank Conselho Nacional de Desenvolvimento Científico e Tecnológico (CNPq) for the scholarships and Universidade do Vale do Taquari - Univates for the financial support granted for this research paper.

\section{CONFLICT OF INTERESTS}

The authors declare they do not have any conflicts of interest.

\section{REFERENCES}

1. Acheson, K.J., Blondel-Lubrano, A., Oguey-Araymon, S., Beaumont, M., Emady-Azar, S., Ammon-Zufferey, C., Monnard, I., Pinaud, S., Nielsen-Moennoz, C., Bovetto, L. (2011). Protein choices targeting thermogenesis and metabolism. The American Journal of Clinical Nutrition, 93(3), 525-534.

2. Amaral, G.V., Silva, E.K., Cavalcanti, R., Martins, C.P.C., Andrade, L.G.Z.S., Moraes, J., Alvarenga V.O., Guimarães, J.T., Esmerino, E., Freitas, M.Q., Silva, M.C., Raices, R.S.L., Sant'Ana, A.S., Meireles, M.A.A., Cruz, A.G. (2018). Whey-grape juice drink processed by supercritical carbon dioxide technology: physicochemical characteristics, bioactive compounds and volatile profile. Food Chemistry, 239, 697-703.

3. Aoi, W.A., Takanami, Y., Kawai, Y., Morifuji, M., Koga, J., Kanegae, M., Mihara, K., Yanohara, T., Mukai, J., Naito, Y., Yoshikawa, T. (2011). Dietary whey hydrolysate with exercise alters the plasma protein profile: a comprehensive protein analysis. $\mathrm{Nu}$ trition, 27(6), 687-692.

4. Areta, J.L., Burke, L.M., Ross, M.L., Camera, D.M., West, D.W.D., Broad, E.M., Jeacocke, N.A., Moore, D.R., Stellingwerff, T., Phillips, S.M., Hawley, J.A., Coffey, V.G. (2013). Timing and distribution of protein ingestion during prolonged recovery from resistance exercise alters myofibrillar protein synthesis. The Journal of Physiology, 591 (9), 2319-2331.

5. Atherton, P.J., Etheridge, T., Watt, P. W., Wilkinson, D., Selby, A., Rankin, D., Smith, K., Rennie, M.J. (2010). Muscle full effect after oral protein: time-dependent concordance and discordance between human muscle protein synthesis and mTORC1 signaling. The American Journal of Clinical Nutrition, 92 (5), 1080-1088.

6. Atherton, P.J., Kumar, V., Selby, A.L., Rankin, D., Hildebrandt, W., Phillips, B.E, Williams, J.P., Hiscock, N., Smith, K. (2017). Enriching a protein drink with leucine augments muscle protein 
synthesis after resistance exercise in young and older men. Clinical Nutrition, 36(3), 888-895.

7. Babault, N., Deley, G., Le, Ruyet P., Morgan, F., Allaert, F.A. (2014). Effects of soluble milk protein or casein supplementation on muscle fatigue following resistance training program: a randomized, double-blind, and placebo-controlled study. Journal of the International Society of Sports Nutrition, 11, art.no. 36.

8. Baer, D.J., Stote, K.S., Paul, D.R., Harris, G.K., Rumpler, W.V., Clevidence, B.A. (2011). Whey protein but not soy protein supplementation alters body weight and composition in free-living overweight and obese adults. Journal of Nutrition, 141 (8), 1489-1494.

9. Bendtsen, L.Q., Lorenzen, J.K., Bendsen, N.T., Rasmussen, C., Astrup, A. (2013). Effect of dairy proteins on appetite, energy expenditure, body weight, and composition: a review of the evidence from controlled clinical trials. Advances in Nutrition: An International Review Journal, 4(4), 418-438.

10. Berryman, C.E., Sepowitz, J.J., McClung, H.L., Lieberman, H.L., Farina, E.K., McClung, J.P. Ferrando, A.A., Pasiakos, S.M. (2017). Supplementing an energy adequate, higher protein diet with protein does not enhance fat-free mass restoration after short-term severe negative energy balance. Journal of Applied Physiology, 122(6), 1485-1493.

11. Biocatalysts. The use of enzymes in the production of whey protein hydrolysates. (2014). Available from [http://www.biocatalysts.com/2015/10/technical-bulletin-the-use-of-enzymes-forwhey-protein-hydrolysis/] (accessed 01 December 2017).

12. Blacker, S.D., Neil, C.W., Joanne, L.F., James, L.J.B., Mark, E.T.W. (2010). Carbohydrate vs protein supplementation for recovery of neuromuscular function following prolonged load carriage. Journal of the International Society of Sports Nutrition, 7(2).

13. Brancaccio, P., Maffulli N., Buonauro, R., Limongelli, F.M (2008). Serum enzyme monitoring in sports medicine. Clinics in Sports Medicine, 27(1), 1-18.

14. Brancaccio, P., Maffulli, N., Limongelli, F.M. (2007). Creatine kinase monitoring in sport medicine. British Medical Bulletin, 81-82. 209-30.

15. Brown, M.A., Stevenson, E.J., Howatson, G. (2018). Whey protein hydrolysate supplementation accelerates recovery from exercise-induced muscle damage in females. Applied Physiology, Nutrition, and Metabolism, 43(4), 324-330.

16. Buckley, J.D., Thomson, R.L., Coates, A.M., Howe, P.R.C., DeNichilo, M.O., Rowney, M.K. (2010). Supplementation with a whey protein hydrolysate enhances recovery of muscle forcegenerating capacity following eccentric exercise. Journal of Science and Medicine in Sport, 13(1), 178-181.

17. Burd, N.A., Yang, Y., Moore, D.R., Tang, J.E., Tarnopolsky, M.A., Phillips, S.M. (2012). Greater stimulation of myofibrillar protein synthesis with ingestion of whey protein isolate v. micellar casein at rest and after resistance exercise in elderly men. The British Journal of Nutrition, 108(6), 958-962.

18. Burke, L.M., Winter, J.A., Cameron-Smith, D., Enslen, M., Farnfield, M., Decombaz, J. (2012). Effect of intake of different dietary protein sources on plasma amino acid profiles at rest and after exercise. International Journal of Sport Nutrition and Exercise Metabolism, 22(6), 452-462.

19. Burnley, E.C.D., Olson, A.N., Sharp, R.L., Baier, S.M., Aleke, D.L. (2010). Impact of protein supplements on muscle recovery after exercise-induced muscle soreness. Journal of Exercise Science \& Fitness, 8(2), 89-96.
20. Cannon, J.G. (2000). Inflammatory cytokines in non pathological states. News in Physiological Sciences, 15(6), 298-303.

21. Cappato, L.P., Ferreira, M., Moraes, J., Pires, R.P.S., Rocha, R.S., Silva, R.C., Neto, R.P.C., Tavares, M.I.B., Freitas, M.Q., Rodrigues, F.N., Calado, V., Raices, R.S.L., Silva, M.C., Cruz, A.G. (2018). Whey acerola-flavoured drink submitted Ohmic Heating: bioactive compounds, antioxidant capacity, thermal behavior, water mobility, fatty acid profile and volatile compounds. Food Chemistry, 263, 81-88.

22. Chen, W.C., Huang, W.C., Chiu, C.C., Chang, Y.K., Huang, C.C. (2014). Whey protein improves exercise performance and biochemical profiles in trained mice. Medicine and Science in Sports and Exercise, 46(8), 1517-1524.

23. Chungchunlam, S.M.S., Henare, S.J., Ganesh, S., Moughan, P.J. (2017). Effects of whey protein and its two major protein components on satiety and food intake in normal-weight women. Physiology \& Behavior, 175, 113-118.

24. Churchward-Venne, T.A., Breen, L., Di Donato, D.M., Hector, A.J., Mitchell, C.J., Moore, D.R., Stellingwerff, T., Breuille, D., Offord, E.A., Baker, S.K., Phillips, S.M. (2014). Leucine supplementation of a low protein mixed macronutrient beverage enhances myofibrillar protein synthesis in young men: a double-blind, randomized trial. The American Journal of Clinical Nutrition, 99(2), 276-286.

25. Cruzat, V.F., Krause, M., Newsholme, P. (2014). Amino acid supplementation and impact on immune function in the context of exercise. Journal of the International Society of Sports Nutrition, 11, art.no. 61.

26. Cruzat, V.F., Rogero, M.M., Tirapegui, J. (2010). Effects of supplementation with free glutamine and the dipeptide alanyl-glutamine on parameters of muscle damage and inflammation in rats submitted to prolonged exercise. Cell Biochemistry and Function, 28(1), 24-30.

27. Cruzat, V.F., Tirapegui, J. (2009). Effects of oral supplementation with glutamine and alanyl-glutamine on glutamine, glutamate, and glutathione status in trained rats and subjected to long-duration exercise. Nutrition, 25(4), 428-435.

28. Davies, R.W., Carson, B.P., Jakeman, P.M. (2018). The effect of whey protein supplementation on the temporal recovery of muscle function following resistance training: A systematic review and meta-analysis. Nutrients, 10(2).

29. Devries, M.C., Phillips, S.M. (2015). Supplemental protein in support of muscle mass and health: advantage whey. Journal of Food Science, 80, Suppl. 1, A8-A15.

30. Duhamel, T.A., Green, H.J., Perco, J.G., Ouyang, J. (2005). Metabolic and sarcoplasmic reticulum $\mathrm{Ca} 2+$ cycling responses in human muscle 4 days following prolonged exercise. Canadian Journal of Physiology Pharmacology, 83(7), 643-655.

31. Erskine, R.M., Fletcher, G., Hanson, B., Folland, J.P. (2012). Whey protein does not enhance the adaptations to elbow flexor resistance training. Medicine and Science in Sports and Exercise, 44(9), 1791-1800.

32. Erskine, R.M., Jones, D.A., Williams, A.G., Stewart, C.E., Degens, H. (2010). Inter-individual variability in the adaptation of human muscle specific tension to progressive resistance training. European Journal of Applied Physiology, 110(6), 1117-1125.

33. FAO. Food And Agriculture Organization of the United Nations. (2013). Dietary protein quality evaluation in human nutrition: report of an FAO expert consultation. Available from [http://www.fao. 
org/ag/humannutrition/35978-02317b979a686a57aa4593304ffc17f06.pdf] (accessed 01 December 2017).

34. Farup, J., Rahbek, S.K., Riis, S., Vendelbo, M.H., Paoli, F., Vissing, K. (2014b). Influence of exercise contraction mode and protein supplementation on human skeletal muscle satellite cell content and muscle fiber growth. Journal of Applied Physiology, 117(8), 898-909.

35. Farup, J., Rahbek, S.K., Vendelbo, M.H., Matzon, A., Hindhede, J., Bejder A., Ringgard, S., Vissing, K. (2014a). Whey protein hydrolysate augments tendon and muscle hypertrophy independent of resistance exercise contraction mode. Scandinavian Journal of Medicine \& Science in Sports, 24(9), 788-798.

36. Gomes, D.L., Moehlecke, M., Silva, F.B.L., Dutra, E.S., D'Agord, S.B., Carvalho, K.M.B. (2017). Whey protein supplementation enhances body fat and weight loss in women long after bariatric surgery: a randomized controlled trial. Obesity Surgery, 27(2), 424-431.

37. Grala A.P., Teixeira M.A.R., Nishitania T.C., Melosi A.F., Jacinto J.L., Aguiar A.F. (2017). Effects of leucine supplementation associated with resistance training on muscle strength in young subjects. Journal of Health Science, 19(2), 63-67 (in Portuguese; English abstract).

38. Guimarães, J.T., Silva, E.K., Freitas, M.Q., Meireles, M.A.A., Cruz, A.G. Non-thermal emerging technologies and their effects on the functional properties of dairy products. (2018). Current Opinion in Food Science, 22, 62-66.

39. Hackney, K.J., Bruenger, A.J., Lemmer, J.T. (2010). Timing protein intake increases energy expenditure $24 \mathrm{~h}$ after resistance training. Medicine and Science in Sports and Exercise, 42(5), 998-1003.

40. Halford, J.C., Boyland, E.J., Lawton, C.L., Blundell, J.E., Harrold, J.A. (2011). Serotonergic anti-obesity agents: past experience and future prospects. Drugs, 71(17), 2247-2255.

41. Hamarsland, H., Laahne, J.A.L, Paulsen, G., Cotter, M., Borsheim, E., Raastad, T. (2017). Native whey induces higher and faster leucinemia than other whey protein supplements and milk: a randomized controlled trial. BMC Nutrition, 3(10).

42. Hansen, M., Bangsbo, J., Jensen, J., Bibby, B.M., Madsen, K. (2015). Effect of whey protein hydrolysate on performance and recovery of top-class orienteering runners. International Journal of Sport Nutrition and Exercise Metabolism, 25(2), 97-109.

43. Haraguchi, F.K., Abreu, W.C., Paula, H. (2006). Whey protein: composition, nutritional properties, applications in sports and benefits for human health. Revista de Nutrição, 19(4), 479-488 (in Portuguese; English abstract).

44. Hector, A.J., Marcotte, G.R., Churchward-Venne, T.A., Murphy, C.H., Breen, L., von Allmen, M., Baker, S.K., Phillips, S.M. (2015). Whey protein supplementation preserves postprandial myofibrillar protein synthesis during short-term energy restriction in overweight and obese adults. The Journal of Nutrition, 145(2), 246-252.

45. Hulmi, J.J., Laakso, M., Mero, A.A., Häkkinen, K., Ahtiainen, J.P., Peltonen, H. (2015). The effects of whey protein with or without carbohydrates on resistance training adaptations. Journal of the International Society of Sports Nutrition, 12, art.no. 48.

46. IOM. Institute of Medicine. (2002/2005). Dietary reference intakes for energy, carbohydrate, fiber, fat, fatty acids, cholesterol, protein, and amino acids (macronutrients): panel on Macronutrients, Subcommittee on Upper Reference Levels of Nutrients,
Subcommittee on Interpretation and Uses of Dietary Reference Intakes, and The Standing Committee on the Scientific Evaluation of Dietary Reference Intakes, Food and Nutrition Board. Available from [https://www.ncbi.nlm.nih.gov/nlmcata$\log / 101237303$ ] (accessed 01 December 2017).

47. Jäger, R., Kerksick, C.M., Campbell, B.I., Cribb, P.J., Wells, S.D., Skwiat, T.M., Purpura, M., Ziegenfuss, T.N., Ferrando, A.A., Arent, S.M., Smith-Ryan, A.E., Stout, J.R., Arciero, P.J., Ormsbee, M.J., Taylor, L.W., Wilborn, C.D., Kalman, D.S., Kreider, R.B., Willoughby, D.S., Hoffman, J.R., Krzykowski, J.L., Antonio, J. (2017). International Society of Sports Nutrition Position Stand: protein and exercise. Journal of the International Society of Sports Nutrition, 14, art.no. 20.

48. Jakubowicz, D., Froy, O. (2013). Biochemical and metabolic mechanisms by which dietary whey protein may combat obesity and Type 2 diabetes. The Journal of Nutritional Biochemistry, 24(1), 1-5.

49. Jakubowicz, D., Wainsteina, J., Landaua, Z., Ahrenc, B., Barnead, M., Bar-Dayana, Froy, O. (2017). High-energy breakfast based on whey protein reduces body weight, postprandial glycemia and $\mathrm{HbA1C}$ in Type 2 diabetes. Journal of Nutritional Biochemistry, 49, 1-7.

50. Joy, J.M., Lowery, R.P., Wilson, J.M., Purpura, M., Souza, E.O., Wilson, S.M.C, Kalman, D.S., Dudeck, J. E., Jäger, R. (2013). The effects of 8 weeks of whey or rice protein supplementation on body composition and exercise performance. Nutrition Journal, 12, art.no. 86.

51. Kankanamge, R., Jeewanthi, C., Lee, N-K., Lee, S-K., Yoon, Y.C., Paik, Hyun-D. (2015). Physicochemical characterization of hydrolysates of whey protein concentrates for their use in nutritional beverages. Food Science and Biotechnology, 24(4), 1335-1340.

52. Kim, J., Chulhyn, L., Joohyung, L. (2017). Effect of timing of whey protein supplement on muscle damage markers after eccentric exercise. Journal of Exercise Rehabilitation, 13(4), 436-440.

53. Koury, J.C., Donangelo, C.M. (2003). Zinc, oxidative stress and physical activity. Revista de Nutrição, 16(4), 433-441 (in Portuguese; English abstract).

54. Kumar, V., Selby, A., Rankin, D., Patel, R., Atherton, P., Hildebrandt, W., Williams, J., Smith, K., Seynnes, O., Hiscock, N., Rennie, M.J. (2009). Age-related differences in the dose-response relationship of muscle protein synthesis to resistance exercise in young and old men. The Journal of Physiology, 587(1), 211-217.

55. Lockwood, C.M., Roberts, M.D., Dalbo, V.J., Smith-Ryan, A.E., Kendall, K.L., Moon, J.R., Stout, J.R. (2017). Effects of hydrolyzed whey versus other whey protein supplements on the physiological response to 8 weeks of resistance exercise in college-aged males. Journal of the American College of Nutrition, 36(1), 16-27.

56. Lollo, P.C.B, Amaya-Farfan, J., Faria, I.C., Salgado, J.V.V., Chacon-Mikahil, M.P.T., Cruz, A.G., Oliveira, C.A.F., Montagner, P.C., Arruda, M. (2014). Hydrolysed whey protein reduces muscle damage markers in Brazilian elite soccer players compared with whey protein and maltodextrin. A twelve-week inchampionship intervention. International Dairy Journal, 34(1), 19-24.

57. Macnaughton, L.S., Wardle, S.L., Witard, O.C., McGlory, C., Hamilton, D.L., Jeromson, S., Lawrence, C.E., Wallis, G.A., Tipton, K.D. (2016). The response of muscle protein synthesis after whole body resistance exercise is greater after $40 \mathrm{~g}$ than $20 \mathrm{~g}$ 
of whey protein ingested. Physiological Reports, 4, art.no. UNSP e 12893

58. Madureira, A.R., Tavares, T., Gomes, A.M., Pintado, M.E., Malcata, F.X. (2010). Invited review: physiological properties of bioactive peptides obtained from whey proteins. Journal of Dairy Science, 93(2), 437-455.

59. Mahan, L.K., Escott-Stump, S. (1998). Proteínas. In: Krause: Alimentos, nutrição e dietoterapia. 9. ed. Roca, São Paulo, pp. 63-76, ISBN: 8572412409 (in Portuguese).

60. Markus, C.R., Oliver, B., Haan, E.H.F. (2002). Whey Protein rich in alfa-lactoalbumin increases the ratio of plasma tryptophan to the sum of the other large neutral amino acids and improves cognitive performance in stress-vulnerable subjects. The American Journal of Clinical Nutrition, 75(6), 1051-1056.

61. Marshall, K. (2004). Therapeutic applications of whey protein. Alternative Medicine Review, 9(2), 136-156.

62. McArdle, W. D., Katch, F. I., Katch, V. L. (2014). Nutrição para o esporte e o exercício. 3th edition. Guanabara Koogan, Rio de Janeiro, RJ. pp. 33-41, ISBN: 9788527716659 (in Portuguese).

63. Mitchell, C.J., D’Souza, R.F., Fanning, A.C., Poppitt, D., Cameron-Smith, D. (2017). Short communication: Muscle protein synthetic response to microparticulated whey protein in middleaged men. Journal of Dairy Science, 100(6), 4230-4234.

64. Mitchell, W.K., Phillips, B.E., Williams, J.P., Rankin, D., Lund, J.N., Smith, K., Atherton, P.J. (2015). A dose- rather than delivery profile-dependent mechanism regulates the "muscle-full" effect in response to oral essential amino acid intake in young men. Journal for Nutrition, 145(2), 207-214.

65. Moberg, M., Apro, W., Ohlsson, I., Ponten, M., Villanueva, A., Ekblom, B., Blomstrand, E. (2014). Absence of leucine in an essential amino acid supplement reduces activation of mTORC1 signalling following resistance exercise in young females. Applied Physiology, Nutrition and Metabolism, 39(2), 183-194.

66. Monteiro, C.A., Cannon, G., Moubarac, J.C., Levy, R.B., Louzada, M.L.C., Jaime, P.C. (2018). The UN decade of nutrition, the NOVA food classification and the trouble with ultra-processing. Public Health Nutrition, 21(1), 5-17.

67. Monteyne, A., Martin, A., Jackson, L., Corrigan, N., Stringer, E., Newey, J., Rumbold, P.L.S, Stevenson, E., James, L.J. (2018). Whey protein consumption after resistance exercise reduces energy intake at a post-exercise meal. European Journal of Nutrition, 57(2), 585-592.

68. Moore, D.R., Robinson, M.J., Fry, J.L., Tang, J.E., Glover, E.I., Wilkinson, S.B., Prior, T., Tarnopolsky, M.A., Phillips, S.M. (2009). Ingested protein dose response of muscle and albumin protein synthesis after resistance exercise in young men. The American Journal of Clinical Nutrition, 89(1), 161-168.

69. Morton, R.W., Murphy, K.T., McKellar, S.R., Schoenfeld, B.J., Henselmans, M., Helms, E., Aragon, A.A., Devries, M.C., Banfield, L., Krieger, J.W., Phillips, S.M. (2018). A systematic review, meta-analysis and meta-regression of the effect of protein supplementation on resistance training-induced gains in muscle mass and strength in healthy adults. British Journal of Sports Medicine, 52(6), 376-384.

70. Naclerio, F., Larumbe-Zabala, E. (2016). Effects of whey protein alone or as part of a multi ingredient formulation on strength, fat-free mass, or lean body mass in resistance-trained individuals: a meta-analysis. Sports Medicine, 46(1). 125-137.
71. Niess, A.M., Simon, P. (2007). Response and adaptation of skeletal muscle to exercise-the role of reactive oxygen species. Frontiers in Bioscience, 12, 4826-4838.

72. Nogiec, C.D., Kasif, S. (2013). To supplement or not to supplement: a metabolic network framework for human nutritional supplements. PLoS One, 8(8), art.no. e68751.

73. Oliveira, D.F., Bravo, C.E.C., Tonial, I.B. (2012). Whey of milk: a valuable product. Revista do Instituto de Laticínios Cândido Tostes, 385. 64-71 (in Portuguese).

74. Ostrowski, K., Rohde, T., Asp, S., Schjerling, P., Pedersen, B.K. (1999). Pro-and anti-inflammatory cytokine balance in strenuous exercise in humans. The Journal of Physiology, 515(1), 287-291.

75. Pal, S., Radavelli-Bagatini, S. (2013). The effects of whey protein on cardiometabolic risk factors. Obesity Reviews, 14(4), 324-343.

76. Pasiakos, S.M., Austin, K.G., Lieberman, H.R., Askew, E.W. (2013). Efficacy and safety of protein supplements for U.S. Armed Forces personnel: consensus statement. The Journal of Nutrition, 143(11), 1811S-1814S.

77. Petry, E.R., Cruzat, V.F., Heck, T.G., Leite, J.S., Homem de Bittencourt, P.I. Jr, Tirapegui, J. (2014). Alanyl-glutamine and glutamine plus alanine supplements improve skeletal redox status in trained rats: involvement of heat shock protein pathways. Life Sciences, 94(2), 130-136.

78. Rahbek, S.K., Farup, J., Müller, A.B., Vendelbo, M.H., Holm, L., Jessen, N., Vissing, K. (2014). Effects of divergent resistance exercise contraction mode and dietary supplementation type on anabolic signalling, muscle protein synthesis and muscle hypertrophy. Amino Acids, 46(10), 2377-2392.

79. Rigon, T.V., Rossi, R.G. (2012). Who and why use dietary supplements? Revista Brasileira de Nutrição Esportiva, 6, 420-426 (in Portuguese).

80. Roberts, J., Zinchenko, A., Suckling, C., Smith, L., Johnstone, J., Henselmans, M. (2017). The short-term effect of high versus moderate protein intake on recovery after strength training in resistance-trained individuals. Journal of the International Society of Sports Nutrition, 14, art.no. 44.

81. Rohde, T.M.D, MacLean, D.A., Richter, E.A., Kiens, B., Pedersen, B.K. (1997). Prolonged submaximal eccentric exercise is associated with increased levels of plasma IL-6. American Journal of Physiology - Endocrinology and Metabolism, 273(1), E85-E91.

82. Soares, L.L., Pimenta, E.M., Barros, A.F.S., Lessa, L.B., Pussieldi, G.A. (2012). Analysis of serum creatine kinase in athletes in college football after an intermittent session. Motricidade, 8(S2), 439-446 (in Portuguese).

83. Sociedade Brasileira de Medicina do Exercício e do Esporte. (2009). Dietary changes, water replacement, food supplements and drugs: evidence of ergogenic action and potential health risks. Revista Brasileira de Medicina do Esporte, 15(3) (in Portuguese).

84. Stark, M., Lukaszuk, J., Prawitz, A., Salacinski, A. (2012). Protein timing and its effects on muscular hypertrophy and strength in individuals engaged in weight-training. Journal of the International Society of Sports Nutrition, 9, art.no. 54.

85. Stefanetti, R.J., Lamon, S., Rahbek, S.K., Farup, J., Zacharewicz, E., Wallace, M.A., Vendelbo, M.H., Russell, A.P., Vissing, K. (2014). Influence of divergent exercise contraction mode and whey protein supplementation on atrogin-1, MuRF1, and FOXO1/3A in human skeletal muscle. Journal of Applied Physiology, 116(11), 1491-1502. 
86. Tahavorgar, A., Vafa, M., Shidfar, F., Gohari, M., Heydari, I. (2014). Whey protein preloads are more beneficial than soy protein preloads in regulating appetite, calorie intake, anthropometry, and body composition of overweight and obese men. Nutrition Research, 34(10), 856-861.

87. Teixeira, F.J., Matias, C.N., Monteiro, C.P., Valamatos, M.J., Reis, J., Tavares, F., Batista, A., Domingos, C., Alves, F., Sardinha, L.B., Phillips, S.M. (2018). Leucine metabolites do not enhance training-induced performance or muscle thickness. Medicine and Science in Sports and Exercise, 32(4), 1020-1028.

88. Tsivitse, S.K., McLoughlin, T.J., Peterson, J.M., Mylona, E., McGregor, S.J., Pizza, F.X. (2003). Downhill running in rats: influence on neutrophils, macrophages, and MyoD+ cells in skeletal muscle. European Journal of Applied Physiology, 90(5-6), 633-638.

89. Uchida, M.C., Nosaka, K., Ugrinowitsch, C., Nosaka K., Aoki M.S. (2009). Effect of bench press exercise intensity on muscle soreness and inflammatory mediators. Journal of Sports Sciences, 27(5), 499-507.

90. Van De Vyver, M., Myburgh, K.H. (2012). Cytokine and satellite cell responses to muscle damage: interpretation and possible confounding factors in human studies. Journal of Muscle Research and Cell Motility, 33(3-4), 177-185.

91. Volek, J.S., Volk, B.M., Gómez, A.L., Kunces, L.J., Kupchak, B.R., Freidenreich, D.J., Aristizabal, J.C., Saenz, C., DunnLewis, C., Ballard, K.D., Quann, E.E., Kawiecki, D.L., Flana- gan, S.D., Comstock, B.A., Fragala, M.S., Earp, J.E., Fernandez, M.L., Bruno, R.S., Ptolemy, A.S., Kellogg, M.D., Maresh, C.M., Kraemer, W.J. (2013). Whey protein supplementation during resistance training augments lean body mass. Journal of the American College of Nutrition, 32(2), 122-135.

92. Waitzberg, D.L, Logullo P. (2006). Proteínas. In Waitzberg, D.L. (Eds.), Nutrição oral, enteral e parenteral na prática clínica, 3th edition. Atheneu, São Paulo, pp. 35-54, ISBN: 9788573792553 (in Portuguese).

93. Wallace, Douglas C. (2011). Genetic and molecular aspects of sport performance. In C. Bouchard, E.P. Hoffman (Eds.), Mitochondrial Medicine in Health and Disease: Interface Between Athletic Performance and Therapeutics, Blackwell Publishing Ltd, Oxford, Inglaterra, Reino Unido, pp. 14-32.

94. Welch, K.D., Davis, T.Z., Van Eden, M.E., Aust, S.D. (2002). Deleterious iron-mediated oxidation of biomolecules. Free Radical Biology \& Medicine, 32(7), 577-583.

95. West, D.W., Burd, N.A., Coffey, V.G., Baker, S.K., Burke, L.M., Hawley, J.A., Moore, D.L., Stellingwerff, T., Phillips, S.M. (2011). Rapid aminoacidemia enhances myofibrillar protein synthesis and anabolic intramuscular signaling responses after resistance exercise. The American Journal Clinical of Nutrition, 94(3), 795-803.

Submitted: 2 July 2018. Revised: 7 October and 21 November 2018. Accepted: 3 December 2018. Published on-line: 22 January 2019. 
